\title{
PERAN BUDAYA DALAM KEHIDUPAN BERAGAMA Kajian Atas Kehidupan Beragama Umat Katolik Sunda Di Cigugur
}

\author{
Cornelius Iman Sukmana
}

\begin{abstract}
:
Religious life is directly related to cultural life. This is observable among Sundanese Catholics in Cigugur. In religious life, the respective Sundanese culture strongly marked its influence. The way one lives his or her religiosity also reflects their culture. It is common that religious people live together with other people of different religious belief and practices. In this context culture helps them to be able to live harmoniously with people from different religions. This article focuses on the history of the Catholic community in Cigugur, Kuningan while inquiring the role of the Sundanese culture in their daily life within their Catholic community
\end{abstract}

Kata-Kata Kunci :

Agama, Kehidupan beragama, kebudayaan, hidup besama, Gereja Katolik Sunda

\section{PENDAHULUAN}

\subsection{Latar Belakang}

Kehidupan beragama di suatu masyarakat tentu terkait dengan bagian kehidupan lainnya. Budaya adalah salah satu aspek dominan dalam kehidupan yang mempengaruhi kehidupan beragama. Fenomena demikian dapat diamati secara kasat mata di banyak tempat, terlebih di pedesaan, di mana hubungan tersebut terlihat sangat intim. Bahasa yang digunakan dalam peribadatan pun sebenarnya adalah sarat dengan muatan budaya, karena bahasa sendiri adalah salah satu aspek budaya juga. Pengaruh modernitas di tengah masyarakat perkotaan cukup jelas dalam kehidupan beragama (secara sederhana, misalnya pengaturan jadual kegiatan keagamaan rupanya dipengaruhi oleh situasi sosio-kultural masyarakat tersebut) (Heitink \& Hartono, 2006: 18). ${ }^{1}$

Tulisan ini akan memfokuskan perhatian pada situasi yang dialami oleh komunitas umat Katolik Sunda (eks-ADS) di Stasi St. Carolus Borromeus Sukamulya, Paroki Kristus Raja CigugurKuningan. Hal menarik yang melatarbelakangi penelitian ini adalah sejarah komunitas tersebut yang sarat dengan pergulatan kulturalnya dalam kehidupan beragama. ${ }^{2}$ Fenomena antropologis yang cukup konkret pula adalah adanya faktor kekerabatan yang masih cukup kuat di masyarakat, tidak hanya dalam satu komunitas agama Katolik, melainkan juga mencakup antar agama yang berbeda, yakni Islam dan kelompok aliran penghayat kepercayaan. Kekerabatan yang mengikat itu disebabkan karena mereka adalah masyarakat Sunda, yang berbudaya dan berbahasa Sunda. Kesundaan inilah salah satu pengikat konkret warga masyarakat tersebut.

\subsection{Permasalahan}

Ada pengaruh budaya dalam kehidupan beragama di tengah umat Katolik. Dalam kehidupan beragama, khususnya bagi umat Katolik Sunda, budaya Sunda turut memainkan perannya yang signifikan. Maka dipertanyakan, peran budaya seperti apakah yang memberi pengaruh penting dalam kehidupan beragama umat Katolik Sunda di sana?

\subsection{Tujuan}

Penelitian ini bermaksud menggambarkan situasi umat Katolik Sunda di Stasi St. Carolus Borromeus, Sukamulya. Dengan menggambarkan 
situasi tersebut maka akan terlihat bahwa ternyata pengaruh budaya dalam kehidupan beragama itu begitu konkret. Pengaruh budaya itu tidak hanya ke dalam kehidupan beragama sendiri, melainkan juga ke luar, yakni sosial.

\subsection{Metode Penelitian}

Untuk menjawab persoalan tersebut, penelitian ini menggunakan pendekatan penelitian kualitatif yang memperhatikan aspek kemendalaman informasi atau data yang diperoleh. Data tersebut dianalisis dan dituliskan kembali berupa kisah-kisah dari hasil amatan yang dicatat selama observasi dan wawancara terhadap sejumlah narasumber.

Hasil penelitian ini akan dipaparkan di sini sebagai berikut. Setelah pendahuluan, akan dibahas tentang pemahaman budaya terlebih dahulu untuk memahami perannya dalam kehidup-an beragama yang menjadi fokus perhatian penelitian ini. Selanjutnya, hasil penelitian akan dipaparkan secara deskriptif kualitatif untuk menggambarkan konteks penelitian lebih dekat, dari sana analisis dan pembahasan dilakukan untuk mengulas pokok persoalan penelitian ini. Dan, akhirnya tulisan ini akan ditutup dengan sejumlah simpulan sebagai catatan akhir.

\section{BUDAYA: SEBUAH PEMAHAMAN}

\subsection{Definisi Budaya}

Definisi "budaya” pada umumnya dipahami sebagai definisi yang kompleks. Budaya atau kebudayaan dapat dianggap sebagai suatu istilah yang definisinya mengikuti si penggunanya meskipun merujuk pada realitas yang objektif juga. Artinya, dapat saja seseorang berpendapat tentang "budaya" atau "kebudayaan”, tetapi yang lain boleh keberatan dengan rumusan yang digunakannya; karena menyangkut penghayatan atas budaya tersebut oleh yang bersangkutan. Keragaman definisi budaya atau kebudayaan ini dapat dibandingkan dengan upaya yang pernah dilakukan oleh A. L. Kroeber dan Clyde Kluchohn dengan menyelidiki 160 buah definisi. Mudji Sutrisno secara ringkas mencoba mengurai peristilahan budaya dan kebudayaan. Di sana ia menunjukkan kesulitan tersendiri dalam memahami definisi kata tersebut jika memahaminya sekedar secara etimologis, juga semantis, karena ada penekanan dan referensi tersendiri untuk istilah tersebut sesuai dengan konteks pemakainya (Sutrisno, 2008:1-3). Kroeber dan Klockhohn membedakan enam kategori atas definisi budaya yang telah mereka inventarisasi sebelumnya, berdasarkan ilmu-ilmu yang mendekatinya.

Menurut ilmu sosiologi, kebudayaan merupakan keseluruhan kecakapan (adat, akhlak, kesenian, ilmu, dan lain-lain) yang dimiliki oleh manusia sebagai subjek dalam masyarakatnya. Dalam sorotan ilmu sejarah, kebudayaan merupakan tradisi yang diturunkan dari generasi ke generasi berikutnya. Ada keberlanjutan pada kebudayaan. Filsafat memahami budaya secara normatif. Sedangkan antropologi budaya memandang aspek tingkah laku manusia sebagai makhluk sosial. Psikologi memperhatikan budaya pada proses penyesuaian, belajar serta pembentukan kebiasaan manusia sebagai subjek yang hidup di tengah lingkungannya. Sedangkan ilmu bangsa-bangsa mengatakan bahwa kebudayaan merupakan bangunan ideologi yang mencerminkan pertentangan antar kelas. Menyaksikan beragamnya definisi "budaya" yang mustahil diseragamkan, Mudji Sutrisno menuliskan "Apapun isi dari definisi kebudayaan, para ahli sepakat bahwa kebudayaan merupakan gejala khas manusiawi”, yakni adanya hubungan timbal balik antara manusia sebagai pribadi-individual, manusia sebagai komunitaskolektif, alam (ruang lingkup kehidupan) dan sejarah (kemewaktuan proses kehidupan). Dengan adanya hubungan itulah, maka gejala kebudayaan dihasilkan (Mudji Sutrisno, 2008: 4-5).

Sebagai gejala khas manusiawi, Mudji Sutrisno membedakan antara manusia dan hewan. Dikatakannya bahwa hewan tidak memiliki kemampuan melakukan transendensi terhadap alam sekitarnya. Hewan merupakan bagian langsung dari dan terikat pada alamnya. Hewan langsung mengambil dari alam apa yang dibutuhkannya. Artinya, hewan hidup di alam pertama. Hewan tidak dapat mengolah bahan mentah dari alam. Sedangkan manusia, dengan kemampuannya untuk berjarak dari alam (bahkan dari dirinya sendiri), ia memiliki kesadaran diri untuk membedakan dirinya dari alam sekitarnya, sekaligus dapat mengambil keputusan secara bebas terhadap kehidupannya, membuatnya hidup di alam kedua, yakni kebudayaan. Dari sini Mudji Sutrisno memaknai "kebudayaan" sebagai "hasil kehendak bebas manusia dan karenanya merupakan gejala khas manusiawi” (Mudji Sutrisno, 2008: 5).

Dengan membedakan manusia dan hewan dalam hal "kebudayaan", Mudji Sutrisno mengingatkan bahwa dulu yang dimaksud dengan kebudayaan adalah suatu perwujudan hidup manusia yang berbudi luhur dan bersifat rohani, seperti: agama, seni, filsafat, ilmu tata negara. 
Sedangkan akhir-akhir ini, kebudayaan menunjuk pada segala aktivitas manusia secara personal maupun komunal, yang tidak hanya mencakup hasil material, seperti karya seni, bangunan, ilmu pengetahuan, alat-alat, dll tetapi juga meliputi cara manusia menghayati kehidupannya sendiri, seperti menghayati kematian, perkawinan, dll (Mudji Sutrisno, 2008:6). Maka, jelaslah di sini dipahami bahwa budaya atau kebudayaan itu mencakup seluruh hajat hidup manusia, baik secara jasmani maupun rohani. Dengan kata lain, kebudayaan tidak semata merujuk pada benda-benda hasil kreasi manusia, melainkan juga menunjuk pada suatu dinamika, sehingga budaya itu bersifat dinamis. Dinamis karena kebudayaan terus berlangsung selama manusia masih terus mencipta dirinya dan dunianya.

\subsection{Budaya Sebagai Pola Makna dan Kese- luruhan Sistem}

Budaya yang dinamis menunjuk pada aktivitas manusia. Dalam hal ini, budaya terkait dengan sikap hidup atau mentalitas pelaku budaya sendiri. Sebab, dengan sikap yang tertentu, atau mentalitas tertentu, seseorang atau suatu komunitas dapat menghadirkan karya-karya cipta, yakni kebudayaan. Adanya referensi terhadap apa yang disebut "budaya" menun-jukkan di sana ada pola-pola tertentu yang membuat sesuatu sebagai "budaya". Pola-pola inilah yang dimaksud oleh Clifford Geertz sebagai "pola makna”. Yakni dengan adanya struktur makna simbolis dari suatu praksis budaya, sehingga apa yang dilakukan oleh manusia itu memiliki arti. Atau dengan kebudayaan, manusia memberi makna pada tindakannya.

Untuk memahami budaya sebagai "pola makna”, bentuk-bentuk konkret material yang dapat ditangkap panca indra dapat menjadi pintu masuk memahami budaya demikian. Hal seperti ini menonjol dalam penelitian Geertz ("Religion as a Cultural Sistem", dalam Antrhopological Approaches to the Study of Religion, 1966: 1-46) yang meneliti budaya Jawa. Oleh sebab itu, mengikuti Geertz (2000: 3) "budaya” tersebut dapat dirumuskan sebagai:

suatu pola makna-makna yang diteruskan secara historis yang terwujud dalam simbolsimbol, suatu sistem konsep-konsep yang diwariskan yang terungkap dalam bentukbentuk simbolis yang dengannya manusia berkomunikasi, melestarikan, dan memperkembangkan pengetahuan mereka tentang kehidupan dan sikap-sikap terhadap kehidupan.
Budaya yang merupakan pola makna-makna tersebut terkait dengan pelaku budaya sendiri, sehingga budaya bersifat simbolis. Atau "budaya" yang dimaksud Geertz sebagai sistem simbol, dengan adanya pola makna-makna atau sistem konsep-konsep yang teraktualisasi dalam bentuk simbol yang dapat dikomunikasikan, merupakan sisi halus atau rohani dari realitas budaya yang padat-pejal-material. Sebagai sisi yang halus dan mendalam, budaya demikian terkait dengan mentalitas atau kerangka berpikir masyarakatnya.

Karena terkait dengan mentalitas, atau dapat disebut juga kerangka berpikir masyarakatnya, maka, mengikuti Koentjara-ningrat, definisi "kebudayaan" menurut ilmu antropologi berarti "keseluruhan sistem gagasan, tindakan dan hasil karya manusia dalam rangka kehidupan masyarakat yang dijadikan milik manusia dengan belajar” (Koentjaraningrat, 1983:182). Pada masyarakat tertentu, masyarakat pribumi misalnya, kebudayaan semacam ini dapat ditemukan karena pada umumnya masyarakat (dan terbentuknya suatu masyarakat) tentu memiliki budaya dan pola kebudayaannya sendiri, yang membentuk ciri khas masyarakat tersebut. Dalam perspektif ini, budaya setempat bagi kalangan tertentu identik dengan "agama setempat”, "agama suku” atau "agama asli".

\section{TENTANG AGAMA}

Sama halnya dengan definisi "budaya" atau "kebudayaan” di atas, "agama” juga memiliki beragam arti sesuai dengan pandangan penganutnya, juga menurut perspektif ilmu-ilmu yang mempelajarinya. Misalnya Agama Islam menggunakan kata "din" untuk memaknai kata "agama”, yang juga menunjuk kepada kelompok lain selain kelompok sendiri, seperti menunjuk kepada kalangan kafir Quraisy: "Bagimu din (agama-)mu dan bagiku din (agama-)ku” (Al Kafirun, 6). Din sendiri sering dimaknai sebagai "lembaga ilahi yang memimpin manusia untuk mencapai keselamatan dunia dan akhirat” (Sena Adiningrat, 2010).

Jika dilihat menurut sumbernya, din terbagi dua, yakni din samawi (agama wahyu) dan din wad'i (agama duniawi/natural religion). Dalam pembedaan ini, kiranya "agama asli" di atas merupakan suatu natural religion, yang bagi kalangan tertentu sukar disebut sebagai agama, sehingga tetap dikategorikan sebagai budaya setempat; atau seperti di Indonesia kelompok tertentu penganut aliran kepercayaan itu disebut kelompok "aliran kepercayaan” begitu saja atau kelompok "penghayat kepercayaan”. 
Selalu ada ketegangan dalam memandang "agama" dan "budaya” seperti di atas. Perspektif dualisme tersebut memang dapat menjadi cara kita memahami diri sendiri dan "yang lain”. Namun ada resiko bahwa yang lain masuk dalam kategori yang kita buat sendiri, sehingga "yang lain" sesungguhnya tidak memiliki tempat sebagaimana adanya. Dengan kata lain, kita dapat saja jatuh pada logika biner, bahwa agamaku yang paling benar dan agama yang lain salah atau sesat. Ada suatu ungkapan yang pernah dikenal dalam perjalanan sejarah Gereja Katolik yakni "extra ecclesiam nula salus”, yang berarti "di luar Gereja tidak ada keselamatan”. Ungkapan demikian sama artinya dengan mengeksklusi yang lain dan mengklaim diri sendiri sebagai yang unggul. Kaum fundamentalis dari berbagai agama juga kerap kali melakukan klaim-klaim keunggulan agamanya melulu dan menutup mata pada eksistensi yang lain. Tentu saja pernyataanpernyataan rasa diri unggul demikian dapat saja memiliki rujukan teologisnya sendiri, tetapi sering sekali refleksi teologis yang berkembang juga tidak seragam. Akibatnya memutlakkan satu rumusan teologis tertentu dapat saja menyimpangkan makna keseluruhan ke dalam satu dimensi tunggal saja. Oleh sebab itu, "agama" supaya dapat merangkum "yang lain”, dapat dipahami dari berbagai perspektif yang membuka kesempatan "yang lain” untuk berdialog. Dengan demikian, "agama” dapat hadir ke hadapan kita sebagai suatu entitas kehidupan manusiawi tersendiri.

Istilah lain yang menunjuk pada "agama" adalah "religi" dan "religion" (bahasa Inggris), yang berasal dari kata "religio" (bahasa Latin) yang akar katanya adalah "religare", kata kerja berarti "mengikat dengan kencang", atau "religere" yang berarti "membaca kembali” atau "membaca berulang-ulang dengan penuh perhatian” (Bagus, 1996:12). Secara ringkas, agama berkaitan dengan hidup manusia serta dunianya dan Tuhan, yang dipahaminya sebagai asal dan tujuan hidup (sangkan paraning dumadi). Sikap manusia dalam beragama terungkap dengan penyerahan diri, seperti doa-doa. Penyembahan ini menemukan bentuknya yang paling konkret dalam bentuk kurban, karena melalui kurban inilah manusia menyerahkan kepada Tuhan apa yang berharga sebagai tanda lahiriah dari penyerahan dirinya sendiri. Dari sini agama dapat berarti sebagai "way of life" lengkap dengan peraturanperaturannya tentang kebaktian dan kewajibannya, sebagai alat untuk mengikat seseorang atau sekelompok orang dalam relasinya dengan Tuhan, sesama manusia dan alam semesta” (Sena Adiningrat, 2010).

Sebagai suatu fenomena sosial, umumnya "agama" dapat diartikan: "Certainly religion is individual matter in any number of ways: in that involves personal emotions and thoughts, -... personal beliefs, ... individual are free to commit themselves to whatever religious system they prefer" (Johnstone, 1983:9). Pernyataan ini mengungkapkan bahwa agama itu memiliki dimensi individual selain yang sosial. Agama di sini lalu menjadi entitas yang berada dalam tataran aktivitas personal, intelektual, kesadaran, sekaligus dalam hal tertentu merupakan substansi yang menjadi pertimbangan-petimbangan tindakan sosial. Sebab sejumlah tindakan personal-religius ternyata memiliki referensinya dalam keberagamaan masyarakatnya.

Sebagai suatu fenomena, agama yang dibicarakan ini dapat menunjuk pada "budaya" yang dibicarakan di atas, yakni agama menunjuk pada aktivitas manusiawi secara personal maupun komunal-kolektif, karena beragama ternyata dapat merupakan suatu "gejala khas manusiawi" (bdk. tentang "kebudayaan” dalam Mudji Sutrisno, 2008: 4), sebab hanya manusia sajalah yang beragama, seperti halnya hanya manusia saja yang berbudaya. Karena pada kenyataannya agama itu membutuhkan ekspresi atau ungkapan, seperti dalam bentuk kata-kata, perilaku atau simbolsimbol yang khas (Bagus, 1996: 14).

Dengan membandingkan agama seperti budaya, maka definisi "agama" dapat dilihat secara antropologis juga. Secara antropologis, Geertz (2000: 5) menuliskan bahwa yang disebut dengan "agama" adalah

sebuah sistem simbol-simbol yang berlaku untuk menetapkan suasana hati dan motivasi-motivasi yang kuat, yang mere-sapi, dan yang tahan lama dalam diri manusia dengan merumuskan konsep-konsep mengenai suatu tatanan umum eksistensi dan membungkus konsep-konsep ini dengan semacam pancaran faktualitas, sehingga suasana hati dan motivasi-motivasi itu tampak khas realistis.

Dalam perspektif Geertz ini, baik "agama" maupun "budaya" merupakan suatu pola maknamakna atau sistem simbol-simbol yang berlaku bagi masyarakat manusia. Karena segala ekspresi manusia yang konkret material merupakan cerminan suasana hatinya. Dengan kata lain ekspresi lahiriah simbolis memiliki referensinya pada realitas yang lain yang lebih mendasar, yakni 
suasana hati dan motivasi-motivasi atau dorongandorongan internal. Dengan munculnya ke dalam bentuk yang lebih konkret material, seperti pemujaan, doa-doa, tata cara keagamaan, dll, suasana hati dan motivasi itu menjadi wajar dan realistis bagi manusia yang menjalaninya.

\section{PERAN BUDAYA DALAM KEHIDUPAN BERAGAMA}

Kiranya cukup jelas bagi kita bahwa ada hubungan yang konkret antara budaya dan agama bagi pelaku yang sama. Sebab baik budaya maupun agama merupakan ekspresi suasana hatinya yang lebih mendalam. Meskipun tampak serupa antara "agama" dan "budaya" dalam perspektif antropologi, kita dapat tetap membedakan keduanya. Amaladoss melihat hubungan antara agama dan budaya dengan mengatakan bahwa agama merupakan unsur terdalam dari budaya, sementara budaya merupakan bentuk ekspresif dari agama tersebut. Amaladoss (1990:11-19) menuliskan:

Religion and culture are linked closely together. Religion is the deepest element in culture, giving it its meaning system in the context of ultimate perspectives. In its turn, culture gives a sosio-historical presence to religious belief and commitment. In simple human communities with cosmic religions there is no separation between religion and culture. (Amaladoss, 1990: 12) ${ }^{3}$

Tulisan Amaladoss tersebut merujuk pada fenomena agama-agama yang hidup di India, di tengah masyarakat yang demokratis. Di sini Amaladoss menunjuk pada agama kosmik, yaitu agama yang masih dipengaruhi oleh alam: tanah, air, angin, api, dll yang dalam konteks ini dapat disejajarkan dengan "agama asli”. Sementara itu, agama-agama besar yang telah bersifat misioner dan mengalami penyebaran melewati batas benua memiliki pandangan yang melampaui visi kosmis dari agama kosmik tersebut. Agama misioner ini dikategorikan dalam istilah agama metakosmik, yakni agama yang memiliki bangunan refleksi teologis yang telah mapan dan menjadi ajaran yang dibakukan.

Kiranya cukup jelas meskipun agak samar juga, bahwa akhirnya "budaya", dalam perspektif Amaladoss, merupakan suatu bentuk kehadiran "agama” yang lebih mendasar. Umumnya "agama” dikaitkan dengan pengharapan akan kehidupan akhir, kehidupan sesudah kematian atau keselamatan (soteriologi-eskatologi). Dalam rangka menghayati kehidupan yang diwarnai dengan pandangan akan akhir kehidupan itulah, umat beragama mewujudkan penghayatannya dalam bentuk praktek keagamaan. Dan praktek itu, yang lebih bersifat lahiriah-material, seperti laku tapa, puasa, ibadat, semadi adalah praktek yang dapat bersifat kultural juga. Dengan demikian, dalam rangka memahami peran budaya dalam kehidupan beragama di sini, pertama-tama kita perlu melihat fenomena kehidupan beragama dalam beragam ekspresinya, yang nyatanya bersifat kultural juga, dan dari sana dapat ditelusuri jejak simbolisnya atau struktur makna di balik praksis religius tersebut hingga ditemukan makna "sejati", yakni keyakinan akan Tuhan yang mendasari hidup manusia dan berada di "luar" diri manusia (beyond the world).

Jelas sekali dalam pembahasan tentang "agama” di atas ternyata bahwa agama membutuhkan bagi dirinya ekspresi berupa kata-kata, perilaku dan simbol-simbol yang manusiawi, yang dapat dimengerti atau dikomunikasikan oleh manusia dalam komunitasnya. Bagus menulis, bahwa "agama yang murni internal, spiritual berlawanan dengan kodrat manusia dan tidak dapat berlangsung lama. Begitu juga hal yang paling lahiriah belaka tanpa perasaan-perasaan batin yang terkait memperlihatkan tanda-tanda kematian agama sejati” (1996: 14). Jadi, memang agama membutuhkan budaya. Di sinilah peran budaya bagi agama.

Kehidupan beragama sendiri sebenarnya menunjukkan dua hal. Pertama manusia berelasi dengan Tuhannya, Yang Mutlak, sebagai asal dan tujuan hidupnya. Namun, sebagai makhluk sosial, manusia berelasi dengan sesamanya juga. Artinya, dalam berelasi secara vertikal dengan Tuhan, manusia tidak dapat mengabaikan relasi horizontalnya dengan sesama manusia dan alam ciptaan lainnya. Bahkan dengan beragama manusia dapat membentuk komunitas-sosialnya yang sama, karena merasa menemukan "jalan" yang sama. Dengan kata lain, agama tidak bisa sekedar sebagai persoalan pribadi (privat), melainkan juga manusia beragama karena adanya dorongan komunitasnya. Dari sini cukup jelas bahwa peran budaya dalam kehidupan beragama, selain menciptakan bagi agama sarana ekspresinya yang lebih konkret dan manusiawi, budaya berperan menciptakan kehidupan beragama yang lebih berbadab (baca: berbudaya), karena beragama rupanya adalah hidup bersama masyarakat-budaya. 


\section{BUDAYA SUNDA (EKS-ADS) DI CIGUGUR DAN SEKITARNYA}

Setiap masyarakat budaya tertentu biasanya memiliki pahamnya sendiri tentang agama maupun budaya. Demikian halnya dengan umat Katolik (eks-ADS, Agama Djawa Sunda). Paham yang mereka miliki sebelum menjadi Katolik adalah paham yang sesuai dengan ajaran ADS. Meskipun mayoritas umat eks-ADS kini menjadi Katolik, bahkan generasi berikutnya yang hadir kemudian karena kelahiran anak sudah hidup dalam atmosfer Katolik, kita masih dapat menemukan jejak kesinambungannya dengan tradisi sebelumnya meskipun agak samar-samar. Seperti masih adanya kaum muda yang terlibat dalam kegiatan seni Sunda, untuk mengiringi Misa.

Paham atau pandangan tentang agama maupun budaya yang samar-samar tersebut diindikasikan dari cara mereka menjawab pertanyaan yang agak ragu-ragu. Keraguan tersebut mengindikasikan bahwa terdapat pemahaman yang belum sertamerta jelas dalam pikiran mereka, alias dalam kehidupan sehari-hari ada penghayatan keagamaan yang bernuansa Sunda, tetapi secara formal ada ajaran Katolik yang sudah ditanamkan di sana. Namun demikian, kita dapat mengatakan bahwa keraguan tersebut juga dapat berarti bahwa mereka rupanya tidak memiliki pemahaman yang jelas tentang "agama” maupun "budaya”. Beberapa contoh ungkapan keraguan atau kesamaran akan definisi yang dimengerti terungkap ketika wawancara berlangsung. Sikap tersebut tergambar dari cara informan menanggapi pertanyaan yang peneliti ajukan, di antaranya ada yang lama merenung, ada juga yang senyumsenyum bahkan tertawa, berusaha mengalihkan perhatian. Namun ketika dibantu dengan contohcontoh konkret dan penjelasan seperlunya, maka barulah informan yang ragu-ragu tersebut dapat menjawab. Artinya, secara teoritis (pemahaman) mungkin saja beberapa informan tidak mengerti, tetapi secara praktis yang samar-samar itu dilakukan juga, yakni kebudayaan.

Berikut ini beberapa tanggapan tentang budaya yang dipahami oleh informan. Menurut si Abah, "Kasundaan teh hartosna anu ngaraos jeung rumaos hirup urang anu aya di Tatar Sunda. Jadi nyepeng kana ageman-ageman teh anu ngarasa sareng rumasa, dahar leueut, ceunah paribasana, tina tanah taneuh ieu," ("Kesundaan itu artinya yang merasa dan mengaku merasa bahwa hidup kita ada di Tatar Sunda. Jadi memegang pegangan-pegangan itu yang merasa dan mengakui makan minum ... dari tanah ini.”), katanya sambil menunjuk tanah di hadapannya, karena kebetulan wawancara tersebut berlangsung di pekarangan pastoran Paroki Kristus Raja, Cigugur. Bagi si Abah, kesundaan atau budaya Sunda dikaitkan dengan asal budaya tersebut, yakni tanah Sunda atau Tatar Sunda. Sebab jika seseorang mengaku sebagai orang Sunda maka ia mesti menyadari dirinya yang berasal dari tanah tempat ia hidup, yakni tanah Sunda. Tanah itulah yang memberi kehidupannya, maka menjadi Sunda dan melestarikan kesundaan sama artinya dengan memelihara tanah tempat kehidupannya. Pandangan demikian masih dapat dikaitkan dengan pandangan ADS yang pernah si Abah hayati, karena dengan usianya yang sangat lanjut, 83 tahun, ia telah menjalani kehidupan sebagai anggota ADS, maka ia juga mengenal cara pikir ADS tersebut.

Pak Cahya, seorang Muslim, juga memiliki pendapatnya sendiri tentang budaya, khususnya budaya Sunda yang dihayatinya. Ketika menuturkan tentang pandangannya tentang budaya Sunda, ia mengatakan

... ngeunaan budaya Sunda, ceuk kuring, meureun pedah kuring salaku urang Sunda, lamun dibandingkeun jeung budaya-budaya anu sejen, ceuk kuring mah pangonjoyna teh budaya Sunda. Onjoyna, hiji handap asor; kadua, leah ka sasama; katilu, silih ajenan; kaopatna, resep sisiwo, tah urang Sunda mah. $^{4}$

(... mengenai budaya Sunda, menurut saya, mungkin karena saya adalah seorang Sunda, jika dibandingkan dengan budaya-budaya yang lain, menurut saya budaya Sunda itu paling menarik (pangonjoyna = paling baik). Baiknya, yang pertama, rendah hati; kedua, menghormati sesama; ketiga, saling menghargai; keempat, orang Sunda itu suka bergurau.)

Selain itu, unggulnya budaya Sunda terlihat dari peribahasa "dina nete taraje, nincak hambalan, lamun dina tatangkalan malapah gedang dina omongan mah." Sebabnya karena "... urang sunda mah boga kecap tina basa rengkak paripolah henteu saukur jeung papada manusa," ("Dalam menginjak tangga ada tahaptahapnya, jika dibandingkan dengan pepohonan ada pepepah papaya (gedang) yang dalam ucapan akan menunjukkan keteraturan tutur." Sebabnya karena "...orang Sunda itu punya istilah dalam hal tingkah laku tidak saja pada sesama manusia.”), lanjut Pak Cahya. Maksudnya bahwa orang Sunda itu dapat menghormati sesama, entah itu yang lebih tinggi tingkatan kedudukannya maupun yang 
lebih rendah. Oleh sebab itu ada bahasa-bahasa yang digunakan untuk tingkat-tingkat bahasa: kasar, sedeng dan lemes. ${ }^{5}$ Selanjutnya ciri orang Sunda demikian,

...handap asor, leah ka sasama, ... tuluy dipadukeun ejeung seni musik anu dipikaresep ku kuring, seni musik Sunda, nikmat, ngeunah didengekeun, ... euweuh bibit-bibit kana kakerasan. Ieu seni Sunda nu asli, ceuk kuring. Conto anu dikenalkeun urang Sume-dang $k a$ Kuningan seni Tarawangsa, ngan dua waditra, ukur petikan nu kitu, euweuh keur pacegcogan pacog-cegan piributeun. Ih ngibing bae ngeunah dua waditra teh. Tuluy kaduana, tina game-lan degung, sok perhatikeun gamelan degung, naha aya degung anu ngajak kana piributeun? Euweuh. Gamelan degung mah nu aya kana piributeun teh. Aya na teh nikmatna teh tumpang kaki diuk kolobot...

(... rendah hati, hormat ke sesama, ... lalu disatukan dengan seni musik yang disukai, seni musik Sunda, nikmat, enak didengarkan. ... tidak ada sumber kekerasan. Ini seni Sunda yang asli, menurut saya. Contoh yang diperkenalkan orang Sumedang ke Kuningan, seni Tarawangsa, hanya dua alat petik (kecapi), tidak ada perkelahian keributan. Menari saja enak dua alat musik itu. Lalu, kedua, dari gamelan degung, perhatikanlah gamelan degung itu, apakah mengajak ke arah keributan? Tidak. Gamelan degung itu tidak mengajak keributan. Yang ada adalah nikmatnya duduk tumpang kaki, sambil merokok kolobot)

Ungkapan Pak Cahya, yang seorang kepala sekolah dasar, bagi saya menarik. Sebab itu tidak saja berupa ungkapan kosong, melainkan disertai dengan praktek dalam kehidupan sehari-hari. Salah satu kisah yang menarik adalah ia pernah ikut mengiringi perayaan Natal di Stasi St. Carolus Borromeus, Sukamulya, dengan memainkan kecapi. Tentu saja ia tidak sendirian, sebab beberapa pemusik yang Katolik juga ikut serta. Namun peristiwa itu sungguh menarik hati umat Katolik, dan memandangnya sebagai suatu kehormatan. Maka jelas, bahwa melalui musik Sunda, meskipun berbeda agama di sana dapat terjalin kerukunan dan persaudaraan. Sebab, musik Sunda tidak mendorong orang untuk terlibat kekerasan dan keributan.

Cara hidup yang diperlihatkan Pak Cahya di atas mencerminkan cara hidup orang Sunda yang ia mengerti. Dan sebenarnya dalam perspektif yang lebih luas, itu merupakan cara hidup Sunda yang juga dipahami oleh beberapa informan yang lain. Artinya kita harus hidup saling menghargai, menghormati, karena perbedaan yang ada itu adalah kehendak Tuhan. Adanya kiri dan kanan mencerminkan adanya perbedaan. Tetapi perbedaan keduanya tidak dimaksudkan untuk dipertentangkan secara dangkal. Perbedaan itu hadir supaya dapat diseimbangkan, "dirajah", sehingga terjalin keharmonisan kehidupan.

\section{PERAN BUDAYA DALAM KEHIDU- PAN BERAGAMA}

Dalam membahas pengaruh kebudayaan dalam kehidupan beragama di sini, saya akan membagi dua pembahasan. Pertama pengaruh budaya dalam kehidupan gerejani yang bersifat ke dalam. Kedua pengaruh kebudayaan yang bersifat kemasyarakatan atau ke luar.

\subsection{Pengaruh Budaya dalam Gereja Katolik}

Mayoritas umat Katolik di Cigugur dan sekitarnya adalah umat Sunda (eks-ADS). Kesundaan yang dimiliki oleh umat Katolik tersebut terlihat jelas dan kental dalam kehidupan beragama Katolik mereka-tentu saja untuk kalangan tertentu ada yang kurang menghayati kesundaannya, misalnya yang lahir di luar kota maupun yang merupakan warga pendatang. Namun demikian, jika pendatang tersebut dapat tinggal cukup lama atau menetap di Cigugur, atau di Tatar Sunda dengan suasana Sundanya yang kuat dapat dimungkinkan bahwa warga pendatang pun akan hidup dengan cita rasa Sunda. Hal ini ditunjukkan oleh beberapa pendatang di Cigugur dan sekitarnya yang mencoba beradaptasi dengan situasi masyarakat Sunda.

Sebagai warga Katolik, kesundaan yang dapat ditunjukkan oleh mereka ada beragam bentuk. Dalam tradisi Sunda ada upacara-upacara adat yang masih dilestarikan di tengah kehidupan umat Katolik sekarang ini. Bahkan di antaranya ada yang digali kembali supaya hidup dan berkembang. Beberapa upacara adat yang khas adalah, upacara maras, yakni memotong rambut bayi yang berusia 40 hari. Upacara ini dimaksudkan untuk menyatakan bahwa bayi tersebut dibebaskan dari kotoran (simbolnya rambut).

Upacara lainnya adalah doa persiapan menjelang perkawinan (di daerah Jawa Tengah dikenal dengan istilah "midodhareni", seperti pernah saya saksikan dan ikuti dari dekat ketika masih tinggal di Yogyakarta). Doa ini biasanya diselenggarakan di salah satu calon pengantin, 
sementara pengantin yang lainnya ikut hadir bersama-sama. Doa ini dimaksudkan untuk persiapan batin menjelang calon pengantin melangsungkan perkawinannya. Selanjutnya, dalam kehidupan keluarga, seorang istri pada saatnya akan mengandung calon bayi. Pada periode tertentu, misalnya mengandung tujuh bulan, di sana diadakan upacara nebus weteng. Pada akhir hidupnya, seorang manusia akan “mulih ka jati mulang ka asal”, kembali ke asal kehidupannya, yakni kembali ke Penciptanya. Dalam budaya Sunda ada juga tradisi yang diikuti oleh warganya. Pada saat ini ada doa-doa peringatan bagi arwah yang meninggal serta mendoakan sanak keluarga yang ditinggal-kannya. Doa arwah macam ini dapat dibandingkan dengan tradisi dalam Islam yang disebut "tahlilan”.

Semua praksis kultural-religius di atas masih dipertahankan oleh masyarakat Sunda (eks-ADS) di Cigugur dan sekitarnya. Mereka terus menjalani cara-cara yang semula mereka hayati ketika masih menganut ADS. Namun demikian, di sana ada perubahan atau penyesuaian yang dilakukan yakni disesuaikan dengan tata cara Katolik. Di sana doadoa yang khas dalam kehidupan umat Katolik diadopsi oleh masyarakat setempat. Sambil melanjutkan budaya yang baik, umat Katolik Sunda (eks-ADS) menggunakan doa-doa yang diajarkan dalam Gereja Katolik.

Perkawinan sendiri merupakan suatu upacara yang penting dan meriah dalam kehidupan masyarakat di sana. Dalam penelitian saya sempat mengikuti dua upacara perkawinan, 11 Juni 2010 dan 10 Oktober 2010. Kedua upacara tersebut menggunakan tata cara adat Sunda. Di sana, pasangan pengantin berdampingan mendengarkan nasihat-nasihat yang disampaikan oleh tetua dalam bentuk tembang atau kawih. Nasihat-nasihat itu merupakan pesan dari orang tua kepada anakanaknya yang akan menjalani hidup baru sebagai pasangan suami istri.

Upacara perkawinan yang menggunakan tata cara adat itu terus dipelihara meskipun mereka sudah menjadi Katolik. Bagi Gereja Katolik sendiri, upacara perkawinan adat seperti itu bisa dianggap tidak harus dilakukan jika kedua mempelai sudah melangsungkan perkawinan di gereja. Jadi, secara teologis, perkawinan Katolik yang sudah disahkan oleh dan disaksikan imam sudah cukup. Dalam Gereja Katolik, perkawinan itu sakramen, yakni tanda kasih keselamatan dari Allah bagi umat-Nya. Sakramen itu dilangsungkan oleh kedua mempelai. Jadi, sakramen perkawinan adalah sakramen yang saling diterimakan oleh pasangan suami istri, sehingga keduanya menjadi tanda kehadiran Allah untuk saling menyelamatkan; secara sederhana keselamatan itu berupa kebahagiaan berdua. Simbol sakramen adalah keduanya, demi kebahagiaan bersama, berjanji untuk setia dalam suka maupun duka, untung maupun malang, seumur hidup.

Perkawinan sebagai sakramen bagi Gereja Katolik sudah cukup. Tetapi pada kenyataannya warga masyarakat setempat merasa tidak cukup jika perkawinan hanya diselenggarakan di gereja dan tidak ada upacara yang khas budaya Sunda. Dalam suatu kesempatan, ketika salah seorang calon akan menikah, kebetulan kakaknya belum menikah, sehingga dalam budaya Sunda ada istilah 'ngaragangan ka lanceukna', maka perkawinan yang akan diselenggarakan dibuat sederhana saja. Alasannya, perkawinan adalah jalan menuju kebahagiaan pasangan suami istri, untuk bahagia apakah harus membiarkan yang lain menderita, misalnya di sini adalah kakaknya? Oleh sebab itu, dalam rangka meng-hargai sang kakak, beberapa sesepuh berpen-dapat supaya tidak perlu dibuat meriah, kecuali sang kakak tidak merasa keberatan bahkan mendukungnya. Sikap hormat kepada yang lain tersebut merupakan cerminan budaya Sunda dalam kehidupan sehari-hari, seperti dituturkan oleh Pak Cahya ketika akan menyelenggarakan suatu pesta perkawinan saudaranya yang rumahnya berdekatan.

Bagi orang Sunda, perkawinan di gereja saja tampaknya tidak cukup. Oleh sebab itu, meskipun tidak ada alasan teologis yang jelas, mereka tetap melanjutkan perkawinan di rumah mempelai dengan berbagai cara, termasuk menampilkan pertunjukan-pertunjukan, seperti nanggap wayang, jaipongan, atau sekedar dengan musik-musik khas Sunda. Dengan memperhatikan hal tersebut, meskipun pihak gereja, khususnya para imam yang bertugas di sana tidak keberatan dan tidak memandang perkawinan dengan upacara adat itu sebagai sesuatu yang perlu dipersoalkan, maka jelaslah bahwa di sana ada geliat budaya dalam beragam bentuknya dalam kehidupan masyarakat setempat.

Mungkin saja kita beranggapan bahwa tidak ada hubungan yang jelas antara upacara adat, seperti perkawinan adat, dengan kegiatan keberagamaan umat tersebut, karena hirarki setempat tidak mempersoalkannya. Namun, karena pelaku adalah orang Sunda dan sekaligus beragama Katolik tentu saja ada hubungannya. Hubungannya ada di dalam diri si pelaku budaya tersebut. Dan tidak harus terlihat kasat mata, karena dapat saja merupakan pergolakan batin. 
Memperhatikan hal tersebut, saya menilai bahwa di sana secara nyata terlihat bahwa budaya sungguh memberi peranan dalam kehidupan beragama seorang. Sekurang-kurangnya budaya itu mewarnai kehidupannya sebagai seorang beragama. Kita dapat membandingkannya dengan umat Katolik di tempat lain. Di tempat lain bisa saja orang tidak perlu menyelenggarakan upacara adat, dan cukuplah dengan upacara di gereja secara Katolik. Namun dengan menghadirkan upacara adat dalam kehidupan seorang Katolik, maka menjadi jelas bahwa ada perbedaan antar orang Katolik sendiri. Dan, budaya sungguh berperan dalam membentuk watak Gereja setempat di sana.

Kegiatan lain yang dapat dianggap sebagai "intervensi" budaya dalam kehidupan beragama adalah penggunaan budaya Sunda dalam misa atau perayaan ekaristi. Misa adalah salah satu upacara yang khas dalam Gereja Katolik. Dalam upacara misa ini, jika sungguh diperhatikan, di sana sarat dengan makna simbolis yang dihadirkan oleh Gereja sendiri. Sehingga bagi Gereja Katolik, sebagai puncak kehidupannya. Misa atau ekaristi dapat dianggap cukup dari dirinya sendiri, karena hanya Allah saja yang sungguh berperan dalam peristiwa itu. Segala simbol yang dihadirkan adalah tanda-tanda lahiriah dari kehadiran yang misteri, dengan puncaknya berupa hosti atau komuni suci, sebagai lambang Tubuh Kristus. Namun demikian, bagi orang Sunda (eks-ADS) rupanya, lagi-lagi apa yang sudah dianggap cukup bagi dirinya, seperti ekaristi, rupanya belum dirasa memuaskan jika tidak menyertakan kehidupan mereka sendiri. Maka di sana dibuatlah satu perayaan ekaristi yang khas Sunda, yakni Misa Rayagungan ${ }^{6}$.

Jelaslah bagi kita sekarang bahwa di Cigugur dan sekitarnya memang terlihat peran budaya dalam kehidupan beragama masya-rakatnya. Peran yang paling sederhana namun tidak begitu dirasakan dampaknya adalah penggunaan bahasa Sunda dalam upacara-upacara keagamaan. Misalnya jika ada ibadat lingkungan, baik upacara maras, doa persiapan perkawinan, nebus weteng, doa arwah, dan doa-doa lingkungan lainnya. Penggunaan bahasa ini sebenarnya penting untuk membantu komunikasi iman di tengah umat beragama Katolik, namun justru persoalan ini tidak begitu dilihat sebagai perkara yang penting bagi kehidupan beragama. Namun demikian, meskipun dengan bahasa yang seadanya, yakni kurang memanfaatkan kekayaan bahasa budaya setempat dengan paribasa, dongeng, dll, pengaruh budaya itu tetap jelas.
Masuknya bahasa Sunda dalam liturgi khas Katolik sendiri, seperti Misa, merupakan satu terobosan yang nyata yang dirasakan oleh umat Katolik Sunda (eks-ADS) di Cigugur. Peran bahasa Sunda demikian sudah dilakukan sejak awal umat eks-ADS menganut agama Katolik, yakni dilakukan oleh para misionaris salib suci (OSC) yang bertugas di Cigugur, atas ijin Uskup Bandung, Mgr. P. M. Arntz, OSC. seperti diungkapkan dalam buku kenangan Catur Dasa Warsa:

Memimpin ekaristi di tengah orang Sunda, yang baru menjadi Katolik, rupanya tidak mudah. Terlebih pada masa sebelum Konsili Vatikan II (1962-1965), misa harus disampaikan dalam bahasa Latin. Maka meskipun belum ada keputusan dari Vatikan mengenai penggunaan bahasa setempat dalam sakramen ekaristi, namun atas kebijakan Mgr. Arntz, OSC (Uskup Bandung) saat itu, para pastor diberi kewenangan untuk menyusun misa suci dalam bahasa Sunda. $^{7}$

Demikianlah sekilas kehidupan beragama umat Sunda (eks-ADS) dalam kehidupannya sebagai orang Katolik.

\subsection{Peran Budaya dalam Kehidupan Bermasyarakat sebagai Umat Beragama}

Peran budaya yang lain adalah peran budaya dalam kehidupan bermasyarakat secara umum. Dengan kata lain, di sini akan ditunjukkan hasil pengamatan saya terhadap peran budaya bagi kehidupan beragama umat Katolik Sunda (eksADS) dalam kehidupannya di tengah masyarkat sekitarnya.

Seperti diungkapkan oleh Pak Cahya tentang budaya Sunda yang pangonjoyna, misalnya dengan adanya sikap soméah ka sasama, hadé tata hadé basa,... maka pergaulan hidup bersama dapat terjalin dengan harmonis. Keharmonisan hidup bersama yang terjalin karena umat Katolik memelihara tata cara adat budi bahasa setempat membuatnya tidak terasing di tengah kehidupannya bersama warga sekitarnya.

Kerukunan hidup bermasyarakat ditunjang oleh adanya sikap saling mengerti di antara warga masyarakat yang ada. Meskipun ada berbagai aliran kepercayaan dan ideologi, jika masingmasing pihak dapat saling mengerti, maka kerukunan hidup bersama dapat diusahakan. Inilah peran konkret dan penting dari budaya dalam kehidupan beragama di Cigugur. 
Ada beberapa kisah yang menarik perhatian bagi saya untuk dilaporkan di sini. Di tengah masyarakat Sunda, perbedaan agama tidak mesti menjadi alasan utama untuk memelihara permusuhan dan pertentangan. Sebab cara hidup yang bertentangan, mencipta keributan atau kerusuhan, itu bukanlah cara hidup yang khas orang Sunda, seperti diungkapkan oleh Pak Cahya, dengan mengatakan bahwa budaya Sunda itu pangonjoyna.

Pandangan dan sikap Pak Cahya, seorang Muslim, ini menarik perhatian saya karena seperti pernah saya dengar kisah dari sejumlah orang Katolik yang lain, mereka sungguh merasa terhormat ketika menyaksikan bahwa ada seorang Muslim, yang mencintai seni Sunda, ikut mengiringi umat Katolik dalam merayakan misa Natal, di gereja St. Carolus Borromeus, Sukamulya. Orang itu adalah Pak Cahya ini. Dan ketika saya wawancarai, dia menunjukkan pandangannya seperti sudah dikutip di atas. Jadi, bagi Pak Cahya, menjadi Sunda itu berarti mau hidup rukun, répéh, rapih, akur, rukun dengan sesama. Perbedaan tidak menjadi hahalang yang merintangi hubungan baik.

Yang dilakukan oleh Pak Cahya adalah contoh bagaimana budaya Sunda berpengaruh dalam kehidupan beragama di tengah masyarakat plurireligius, seperti di Cigugur. Dan di tengah masyarakat tersebut pula Gereja Katolik, yang notabene adalah orang Sunda, dapat bergaul secara Sunda. Di sini kehidupan beragama yang terkesan eksklusif karena sering dianggap terbatas di ruang ibadat, dalam acara-acara liturgis dan terkurung dalam kekakuan protokoler tata cara ibadat yang dibakukan, terbuka untuk bernafas lega dalam kehidupan konkret bersama "yang lain”.

Kehidupan beragama yang terbuka di tengah masyarakat yang lain adalah kehidupan beragama yang dapat dianggap sudah dewasa, karena kenyataannya adalah hidup bersama dengan "yang lain”, yang berbeda pandangan, agama, politik, ras, dll tidak mungkin dihin-darkan, maka cara yang efektif untuk hidup bersama dengan yang lain adalah hidup dengan cara yang dapat diterima bersama. Dan, budaya Sunda adalah salah satu budaya yang diterima oleh masyarakat Sunda meskipun berbeda-beda agama. Jadi peran budaya dalam kehidupan beragama di sini adalah membantu kehidupan umat beragama supaya dapat hidup bersama dengan umat beragama yang lain.
Menyadari hal itu, beberapa tokoh Katolik yang ada di Cigugur dan sekitarnya, seperti di Sukamulya, sering mengadakan kumpulan bersama, atau riungan, sekedar untuk ngobrol ngalér ngidul. Kebersamaan hidup bersama "yang lain" ini dapat dilihat tidak saja di kalangan tertentu yang menyadari pentingnya hidup bersama, di kalangan remaja dan kaum muda juga mereka lakukan. Artinya budaya Sunda memang memandang keharmonisan, kerukunan, kebersamaan itu sesuatu yang perlu dipelihara. Istilah yang digunakan oleh Ibu Maria, ketika ia masih aktif mengajar, sementara di dekat sekolahnya ada pesantren yang cukup besar, adalah "nitipkeun awak" atau "miha-pékeun diri". Artinya, di mana kita berada kita harus bisa menyesuaikan diri, karena kita hidup tidak untuk diri sendiri. Oleh sebab itu, menghormati yang lain perlu dilakukan supaya hidup rukun terpelihara. Dan kisah $\mathrm{Bu}$ Maria ini sungguh mengesankan. Meskipun ia seorang Katolik, yang ketika masih muda sangat aktif dalam kegiatan keagamaannya, ternyata ketika ia akan meninggalkan sekolah karena dimutasi sebagaimana PNS lainnya (dan bahkan ketika pensiun), banyak sekali warga sekitar sekolah, yang Muslim, mengantarnya. Kisah lain adalah, ada juga beberapa orang Muslim yang akan naik haji, berkunjung dulu ke rumah Bu Maria, untuk pamitan dan mohon didoakan. Karena bagi pandangan orang tua, siapa pun yang akan berangkat jauh, karena tidak akan diketahui bagaimana nasibnya nanti, maka perlulah saling memaafkan dan memohon doa. Dan kisah ini memberi inspirasi, karena ternyata hidup bersama sebagai orang Sunda itu memiliki warna tersendiri di tengah umat beragama (tanpa kehilangan identitas keagamaan itu sendiri).

\section{PENUTUP}

Pengaruh budaya dalam kehidupan beragama sungguh nyata. Tidak hanya berlaku dalam kehidupan umat Katolik eks-ADS di Cigugur, tetapi dapat disaksikan dibanyak tempat di mana masyarakat budaya tertentu menganut suatu agama. Dari penelitian yang sudah dilakukan, ada beberapa hal yang dapat menjadi simpulan.

Berdasarkan sejarah terbentuknya, Gereja Katolik di Cigugur dan sekitarnya adalah suatu komunitas yang berawal dari sekelompok umat yang menganut suatu agama, yang di sini dikategorikan sebagai "agama asli" atau "agama pribumi”. Agama tersebut adalah Agama Djawa Sunda (ADS). Namun dalam perspektif "agama resmi” di Indonesia, ADS tidak dikategorikan sebagai agama; oleh sebab itu organisasi tersebut 
dibubarkan oleh P. Tedja Buana, pada tanggal 21 September 1964. Pasca pembubaran ADS, ribuan umat mendaftarkan diri menjadi anggota Gereja Katolik, mengikuti P. Tedja Buana. Berdasarkan hasil penelitian, masuknya umat eks-ADS ke dalam Gereja Katolik ternyata diikuti oleh budaya (religius) yang mereka anut sebelumnya.

Pengaruh budaya dalam kehidupan beragama yang tampak dalam kehidupan umat eks-ADS di Cigugur dapat ditunjukkan dalam beragam bentuk yang hadir dalam berbagai peristiwa. Dalam kehidupan sehari-hari, penggunaan bahasa Sunda membuat budaya tetap hidup dalam kehidupan umat Katolik di sana. Hal ini terlihat dalam peristiwa-peristiwa keagamaan, seperti ibadat yang diselenggarakan di tengah umat, di rumahrumah penduduk. Umumnya ibadat ini menggunakan bahasa setempat, kadang di antaranya cara pikir dan merasa yang khas budaya setempat digunakan di sini.

Perkembangan umat Katolik di Cigugur lebih dominan dalam bentuk kelahiran anak. Dalam peristiwa ini, budaya Sunda eks-ADS kadang masih dapat ditemukan juga. Istilah "maras" atau mencukur rambut bayi setelah berumur 40 hari merupakan upacara adat Sunda di sana. Namun bagi orang Katolik upacara adat tersebut diangkat dalam kehidupan beragama sehingga diselenggarakan ibadat khusus. Dengan kata lain, pengaruh budaya setempat di sini terlihat yakni membentuk tradisi keagamaan dalam bentuk ibadat maras bayi.

Selain peristiwa kelahiran, perkawinan dan kematian juga merupakan peristiwa yang hidup di tengah umat yang kental dengan nuansa budaya. Keterlibatan berbagai pihak dalam peristiwa ini tidak dibatasi oleh agama tertentu saja. Artinya peristiwa penting dalam kehidupan manusia tersebut mengundang umat berbagai agama untuk hadir dan menyaksikannya. Kehadiran berbagai umat beragama tersebut dipersatukan oleh rasa kemanusiaan yang teraktualisasi dalam wujud budaya. Jadi, budaya dalam kehidupan bersama dapat menjadi praksis keberagamaan seseorang. Dengan kata lain, "budaya" berperan menghadirkan berbagai kalangan dari berbagai kepercayaan atau agama yang berbeda-beda. Maka budaya merupakan pemersatu berbagai umat, sehingga toleransi dan pluralisme menjadi terwujud.

Bersatunya umat dari berbagai agama dalam peristiwa-peristiwa kemanusiaan di atas dapat dikaitkan juga dengan faktor kekerabatan yang hidup di tengah umat tersebut. Hal ini dapat dilihat pada sejarah pembubaran ADS. Selain menjadi anggota Gereja Katolik, sejumlah umat eks-ADS rupanya ada yang masuk ke agama-agama resmi lainnya, seperti Islam dan Protestan. Dengan demikian, berbeda-beda agama tidak menjadi alasan terjadinya perpecahan. Melainkan karena memiliki sejarah kekerabatan yang sama, maka peran budaya konkret sebagai pemersatu umat beragama di sana.

\section{Cornelius Iman Sukmana \\ Pengajar di Prodi Ilmu Pendidikan Teologi, Unika Atma Jaya, Jakarta, Email:cornelius.iman@atmajaya.ac.id}

\section{CATATAN AKHIR}

1 Dalam tulisannya, Heitink \& Hartono menuliskan bahwa: "gagasan mengenai modernitas sebagai konteks pastoral di Indonesia didasarkan atas hukum sosiologis yang mengatakan bahwa gejala modernitas muncul ketika terjadi transisi dari budaya agraris ke budaya industri." Gambaran demikian konkret terjadi di tengah masyarakat perkotaan, atau sekurangkurangnya daerah yang tengah menuju kea rah tersebut.

2 Tentang sejarah singkat umat Katolik Sunda di Cigugur dapat dibaca dalam tulisan C. Iman Sukmana, Menuju Gereja yang Semakin Pribumi: Analisis Konflik Internal dalam Gereja Eks-ADS. Jakarta: Penerbit Atma Jaya, 2011.

3 “Agama dan budaya bersama-sama terhubung secara tertutup. Agama merupakan elemen terdalam dari budaya, yang memberikan sistem makna padanya dalam konteks berbagai perspektif yang ultim. Sebaliknya, budaya memberikan suatu kehadiran yang bersifat sosio-historis terhadap kepercayaan dan komitmen religius. Dalam komunitas manusiawi yang sederhana dalam agama-agama kosmik di sana tidak ada pemisahan antara agama dan budaya.” (1990: 12)

4 Wawancara, hari Sabtu, 17 Juli 2010, 15.00-16.30 WIB, di rumahnya di Sukamulya.

5 Undak-unduk basa atau tingkat-tingkat bahasa ini dikenal dalam budaya Sunda. Dalam sejumlah tulisan ada yang mengatakan bahwa undak-usuk bahasa ini rupanya dipengaruhi oleh undak usuk bahasa yang diproduksi oleh kerajaan Mataram (Ajip Rosidi, 2007: 21). Di sini Ajip mengacu pada G. Moedjanto, "Konsolidasi Kedudukan Dinasti Mataram lewat Pengembangan Bahasa Jawa”, Yogyakarta, Basis, Juli-September, hh. 267-278 dan hh. 295-311.

6 Misa Rayagunan adalah satu Misa yang diselenggarakan di Cigugur dengan sangat meriah. Misa ini terinspirasi oleh upacara adat Sunda, yakni Upacara Seren Taun atau Pesta Nutu.

7 Buku kenangan 40 tahun imamat Rm. A. Rutten, OSC, Cigugur, 2004, h. 39`

\section{DAFTAR RUJUKAN}


2000. Kebudayaan dan Agama, (A. Budi Susanto, Penerjemah). Kanisius, Yogyakarta

Amaladoss. Michael. 1990. "The Encounter of Religions”, Making All Thing New: Dialog, Pluralism \& Evangelization in Asia. Maryknoll, Orbis Books, New York.

Bagus, Lorens. 1996. Kamus Filsafat. Jakarta: Gramedia.

Bakker. Y.W.M. 1976. Agama Asli Indonesia. Seri Puskat No. 95. S.,T.Kat Pradnyawidya, Yogyakarta.

Geertz, Clifford. 1966. "Religion As a Cultural System”, dalam Benton, Michael. Anthropological Approaches to the Study of Religion. Routledge, Great Britain.

Heitink, Gerben \& Ferd. Heselaars Hartono, SJ. 2006. Teologi Praktis: Pastoral dalam Era Modernitas-Postmodernitas. Kanisius, Yogyakarta.
Iman Sukmana, C. 2011. Menuju Gereja yang Semakin Pribumi: Analisis Konflik Internal dalam Gereja eks-ADS. Penerbit Atma Jaya, Jakarta.

Johnstone, Ronald L. 1983. Religion in Society, a Sociology of Religion. Prantice-Hall, London.

Koentjaraningrat. 1983. Pengantar Antropologi.

Mudji Sutrisno, F.X. 2008. Filsafat Kebudayaan: Ikhtiar Sebuah Teks. Ttt: Hujan Kabisat.

Sena Adiningrat, K.P. 2010. "Eksistensi 'Agama Asli Indonesia' dan Perkembangannya dari Masa ke Masa”, makalah disampaikan dalam Sidang Mahkamah Konstitusi dalam rangka Permohonan Uji Materi Undang-undang No. 1/PNPS/1965, di Jakarta, 23 Maret 2010. 